\title{
Effect of Soil Application of AG3 Phosphonate on the Severity of Clubroot of Bok Choy and Cabbage Caused by Plasmodiophora brassicae
}

\author{
P. A. Abbasi and G. Lazarovits, Southern Crop Protection and Food Research Centre, Agriculture and Agri-Food \\ Canada, 1391 Sandford St., London, Ontario N5V 4T3, Canada
}

\begin{abstract}
Abbasi, P. A., and Lazarovits, G. 2006. Effect of soil application of AG3 phosphonate on the severity of clubroot of bok choy and cabbage caused by Plasmodiophora brassicae. Plant Dis. 90:1517-1522.

Field trials were carried out to test the effect of phosphonate fungicide (AG3) on the severity of clubroot of bok choy (Brassica rapa var. chinensis) and cabbage (B. rapa var. perkinensis and $B$. oleracea var. capitata) in commercial Ontario muck fields with a clubroot history. Disease severity also was examined in the same infested soil under greenhouse and microplot conditions. In microplot trials with bok choy, AG3 phosphonate concentrations of 0.07 and $0.14 \%$ a.i. applied before or after planting consistently reduced clubroot severity (1-to- 4 rating) by 0.8 to 1.6 when planted in May or June. However, only the $0.14 \%$ a.i. preplanting treatment was effective in trials in July and August. Postplanting drenches of $0.14 \%$ a.i. were consistently effective throughout the season. Fresh weight of bok choy was increased or not affected by phosphonate treatments. Under field conditions, one $(0.07,0.14$, and $0.21 \%$ a.i. $)$ or two $(0.07 \%$ a.i. $)$ postplanting drench applications of phosphonate significantly reduced the incidence of clubroot by 52 to $87 \%$ and severity by 1.7 to 2.5 on bok choy in 2004 but not in 2005. In the 2004 trial, two applications of $0.07 \%$ a.i. AG3 phosphonate reduced the severity of clubroot comparably to single applications at 0.14 and $0.21 \%$ a.i. rates. Fresh weight of bok choy was increased by 34 to $86 \%$ with all phosphonate drench treatments in both years. With cabbage, AG3 postplanting drench treatments consistently reduced the severity of clubroot (1-to-5 rating) by a range of 0.7 to 3.3 under greenhouse, microplot, and field conditions. In the greenhouse, a single drench application of 0.07 and $0.14 \%$ a.i. AG3 phosphonate 1 day after transplanting cabbage seedlings to the infested muck soil reduced clubroot severity by 2.6 to 3.3 and increased fresh weight of cabbage tops by 66 to $69 \%$. Similar results were seen with cabbage trials under both microplot and field conditions at all AG3 postplanting drench concentrations.
\end{abstract}

Additional keywords: clubroot control, postplanting drench, preplanting amendment

Clubroot, caused by the soilborne fungus Plasmodiophora brassicae Woronin, is one of the most serious diseases of cruciferous vegetables in temperate regions worldwide affecting broccoli, Chinese cabbage, cabbage, cauliflower, radish, turnip, oilseed rape, and other species. Clubroot has become a limiting factor for production of Asian vegetable brassica crops in organic (muck) soils in Ontario, Canada. The pathogen gains entry to the susceptible host through root hairs and induces abnormal growth of affected parts, resulting in malformed and enlarged roots (23). Such roots are not functional for absorption of water or nutrients. Excessive soil moisture and low $\mathrm{pH}$ favor the infection, although disease can occur over a wide range of conditions, leading to serious crop losses. The resting spores of the

Corresponding author: P. A. Abbasi

E-mail: abbasip@agr.gc.ca

Accepted for publication 7 July 2006.

DOI: 10.1094/PD-90-1517

(C) 2006 The American Phytopathological Society fungus can survive in the soil for long periods, making it very difficult to manage clubroot.

Crop rotation, raising soil $\mathrm{pH}$, and improving drainage conditions can provide some level of disease protection; however, under high clubroot pressure, disease control generally is not satisfactory. Other clubroot management options tested on a small or large scale with varying results include use of biological control agents such as root endophytic fungus Heteroconium chaetospira (33) or Phoma glomerata (3); decoy crops such as leafy daikon (29); fungicides such as cyazofamid (27), fluazinam (11,37), and flusulfamide (39); nonionic surfactants (19); plant chemicals or extracts $(18,34)$; or integrated management. Soils suppressive to clubroot also have been reported $(31,41,42)$. Resistance to clubroot is known $(20,22,38)$, but new races of the pathogen can appear quickly $(13,24)$.

Phosphonates, esters of phosphonic acid, are known to control plant diseases caused by Phytophthora spp. $(7,16)$ and downy mildew pathogens (35). Their efficacy against Pythium spp. $(1,2)$ and other fungal pathogens (9) also has been de- scribed. Various salt-based formulations of phosphorus acid and its esters have been used as agricultural fungicides. For example, fostyl-Al (Aliette WP) was registered in 1977 (16) and is still an effective fungicide. Phosphonates are absorbed rapidly and translocated within the plant in both the xylem and phloem (6). They can persist in plant tissues for extensive periods (5), have protective and curative properties $(25,40)$ and a complex mode of action, ranging from direct toxicity against invading pathogens to indirect effects such as activation of host defense responses $(14,15)$. These compounds are applied on foliage as sprays (7), in tree trunks as injections (8), or to soil as drenches (12) to control Phytophthora diseases. There is no published record of the use or efficacy of phosphonates against clubroot.

In previous studies $(1,2)$, we observed that applying AG3 phosphonate (Calirus 150 , liquid formulation, $10.45 \%$ a.i. phosphorus acid and copper sulphate, with citrate as a chelating agent) to muck soils reduced the incidence and severity of Pythium disease on cucumber as well as those of clubroot on bok choy. The objectives of this study were to investigate in greater detail the efficacy of AG3 phosphonate for control of clubroot of bok choy and cabbage as a preplanting amendment or postplanting drench treatment in microplot trials and as postplanting drench treatments in field trials. The effect of AG3 phosphonate treatments on plant fresh weight also was investigated.

\section{MATERIALS AND METHODS}

Plant material and soils. Fungicidefree seed of white Chinese leaf cabbage (Brassica rapa var. chinensis 'Bok Choy') were obtained from a grower located near Holland Marsh, Ontario, Canada. The grower also provided transplants of Chinese cabbage (B. rapa var. perkinensis) for greenhouse, microplot, and field trials during 2005. Transplants of cabbage ( $B$. oleracea var. capitata 'Gideon' or 'Saragota') for 2004 microplot and field trials were obtained from Muck Research Station, Kettleby, Ontario. Samples of muck soils (organic matter 50 to $60 \%, \mathrm{pH}$ 6.4 to 6.8 ) with a history of clubroot were collected from commercial vegetableproducing sites near Holland Marsh and Muck Research Station, Kettleby, Ontario.

Phosphonate formulation and application. The AG3 phosphonate formulation 
was supplied by Bromine Compounds Ltd., Beer Sheva, Israel. Various concentrations of AG3 were applied as a preplanting amendment in some trials or as a postplanting drench in most trials. AG3 was diluted in tap water and either incorporated into the infested muck soil as an amendment before planting or applied as a drench immediately after planting.

Determining the effect on clubroot of bok choy in microplot and field trials. Microplot trials. The potential of AG3 phosphonate as a preplanting amendment or postplanting drench to control clubroot of bok choy was determined in naturally infested muck soils collected from two commercial fields near Holland Marsh or Muck Research Station, Kettleby. The infested soils from the field sites were brought to London, Ontario for microplot trials. In 2004, trials were planted in May, June, July, and August; whereas, in 2005, replicated trials were conducted throughout the season, with planting in June, July, August, and September. In both years, fresh muck soil was used for each trial.

Plastic drainage tiles $(25 \mathrm{~cm}$ in diameter by $25 \mathrm{~cm}$ long) buried in a sandy loam soil constituted microplots. The bottom $12 \mathrm{~cm}$ of each microplot was filled with the same sandy loam soil. Naturally infested muck soils from field sites were added to the top $12 \mathrm{~cm}$ of each microplot (4 kg/microplot). Treatments included an untreated control and various concentrations $(0.035$ to $0.14 \%$ a.i. vol/mass soil) of AG3 phosphonate, applied as a preplanting amendment or postplanting drench, and were arranged in a completely randomized design with five replicate microplots per treatment. As a preplanting amendment, AG3 phosphonate was incorporated into the infested muck soil in plastic bags and mixed thoroughly. The amended and unamended soils were placed into microplots and 20 bok choy seed were planted by hand in each microplot to a depth of 1 to $2 \mathrm{~cm}$. The drench solutions were prepared fresh by mixing AG3 phosphonate in tap water and were applied as $400-\mathrm{ml}$ volumes per microplot with watering cans after planting. Microplots were watered as required. After 2 weeks, plants were thinned to 10 per microplot. Plants were rated 6 weeks after planting for clubroot severity using a 1-to4 rating scale (Fig. 1), in which $1=0 \%$ (no club), $2=<25 \%$ (small club), $3=26$ to $50 \%$ (medium club), and $4=>50 \%$ (large club) of root surface covered with club. After rating, the plants also were weighed to determine plant fresh weight per microplot.

Field trials. Field trials were carried out on a muck soil with a history of clubroot located near the Holland Marsh. The efficacy of AG3 phosphonate was tested as postplanting drench treatments in 2004 and 2005. Treatments were arranged in a randomized block design with four replicates per treatment. Infested soil from field plots also was brought to London, Ontario for tests in microplots, as described above. The size of each plot was 3 by $1.5 \mathrm{~m}$ in 2004 and 4.5 by $1.2 \mathrm{~m}$ in 2005 . All plots received the fertilizer regime used by the grower at the rate of $660 \mathrm{~kg} / \mathrm{ha}$ (a mixture of $195 \mathrm{~kg}$ of mono ammonium phosphate, $173 \mathrm{~kg}$ of potassium magnesium, $193 \mathrm{~kg}$ of muriate of potash, $91 \mathrm{~kg}$ of ammonium nitrate, and $8 \mathrm{~kg}$ of boron) before planting. Treatments included a control and postplanting drench concentrations of 0.07 , 0.14 , and $0.21 \%$ a.i. AG3 phosphonate. Bok choy seed were planted $5 \mathrm{~cm}$ apart with a planter (five rows in 2004 and four rows in 2005 per replicate plot). The drench solutions were prepared fresh at the site by mixing AG3 phosphonate with tap water, and applied with watering cans at volumes of 15 liters (2004) and 30 liters (2005) per plot immediately after planting. The second drench application was made 2 weeks after planting. Eight weeks after planting, 40 plants were harvested from each plot, rated for clubroot severity as described above, and weighed together to determine fresh weight per plot. In 2004, incidence of clubroot also was determined by calculating the percentage of plants showing clubroot symptoms.

Determining the effect on clubroot of cabbage in greenhouse, microplot, and field trials. Greenhouse trial. Plastic pots (15 $\mathrm{cm}$ in diameter) were filled with the infested muck soil $(1.2 \mathrm{~kg} / \mathrm{pot}, 10$ pots per treatment) from Holland Marsh and each was planted with one cabbage transplant. The drench solutions of AG3 phosphonate
(0.07 and $0.14 \%$ a.i. vol/mass soil) were applied in $200-\mathrm{ml}$ volumes per pot with a watering can 1 day after transplanting. Control pots were drenched with water. Pots were kept in a greenhouse at 22 to $24^{\circ} \mathrm{C}$ under a combination of daylight and supplemental lighting (light intensity 225 $\mu \mathrm{E} \mathrm{m} \mathrm{m}^{-2} \mathrm{~s}^{-1}$ for $12 \mathrm{~h} /$ day) in a completely randomized design. Pots were watered daily as required. Seven weeks after planting, plants were rated for clubroot severity using a modified (27) 1-to-5 rating scale, in which $1=$ none, $2=<25 \%, 3=26$ to $50 \%, 4=51$ to $75 \%$, and $5=>76 \%$ of root surface covered with club. Fresh weight of cabbage tops was determined as well.

Microplot trials. The effect of postplanting drench treatments was determined in naturally infested muck soil from Holland Marsh in 2004 and 2005. In the 2004 microplot trial, $0.035 \%$ a.i. of AG3 phosphonate was tested as a postplanting drench against clubroot on 'Gideon' cabbage. Infested soil from Holland Marsh was used in microplots, as described above. There were 11 replicate microplots (each containing one transplant) per treatment arranged in a completely randomized design. Plants were harvested 8 weeks after planting and rated for clubroot severity using a 1-to-5 rating scale as described above.

In 2005, microplots described above but without drainage tiles (holes $25 \mathrm{~cm}$ in diameter by $25 \mathrm{~cm}$ long) were filled with infested muck soil, and one Chinese cabbage seedling was transplanted per microplot. Treatments included an untreated control and AG3 postplanting drench concentrations applied once $(0.035,0.07$, and $0.14 \%$ a.i. vol $/ \mathrm{mass}$ soil) or twice $(0.035$ and $0.07 \%$ a.i. vol/mass soil) and were arranged in a randomized block design with four replicates (five transplants per replicate) per treatment. AG3 drench solutions were mixed with tap water and applied as 400-ml volumes per plot with watering cans 1 day after transplanting cabbage. The second drench application was made 3 weeks after the first application. Microplots were watered as required. Plants were harvested 10 weeks after planting and individual roots were rated for clubroot severity using a 1-to-5 rating scale as described above for greenhouse

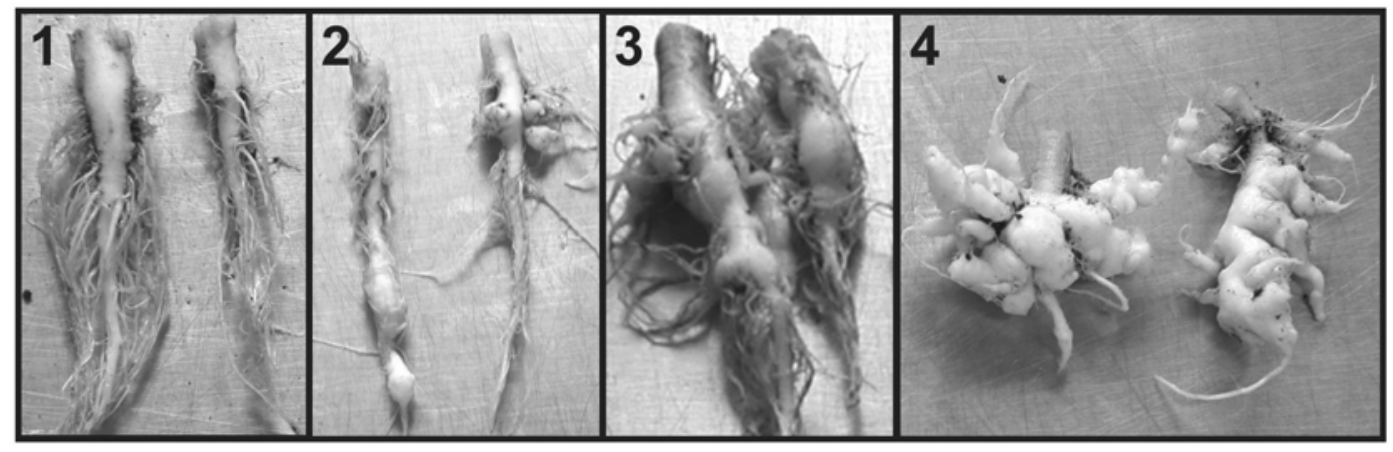

Fig. 1. A 1-to-4 rating scale for clubroot severity on bok choy. 
trials. The fresh weight of cabbage heads per plot was determined as well.

Field trials. The efficacy of AG3 phosphonate as postplanting drench treatments was tested against clubroot of cabbage in the infested muck field plots at Kettleby in 2004 and at Holland Marsh in 2005. Infested soil from field plots was brought to London, Ontario for additional testing in the greenhouse and microplot trials as described above. In the 2004 trials at Kettleby, treatments included a control and a postplanting drench concentration of $0.035 \%$ a.i. phosphonate. The treatments were arranged in a randomized block design with four replicates per treatment. Each plot ( 4 by $3 \mathrm{~m}$ ) consisted of four rows of 'Saragota' cabbage plants (13 plants per row). The AG3 phosphonate drench treatment was applied 2 days after transplanting in 200-ml volumes per plant. All plots received the same amount of NP-K fertilizer 3 to 4 days before planting at the rate of $100 \mathrm{~kg}$ of $\mathrm{N}, 20 \mathrm{~kg}$ of $\mathrm{P}_{2} \mathrm{O}_{5}$, and $120 \mathrm{~kg}$ of $\mathrm{K}_{2} \mathrm{O}$ per hectare in the form of ammonium nitrate 34-0-0, mono ammonium phosphate 11-52-0, and muriate of potash 0-0-60. Eight weeks after planting, 12 plants from the middle two rows of each plot were harvested, their roots evaluated for clubroot severity using a 1-to-5 scale as described above, and the heads weighed to determine fresh weight per plant.

In the 2005 Holland Marsh trial, all plots $(4.5$ by $1.2 \mathrm{~m}$ ) received the fertilizer regime used by the grower as described for bok choy. Treatments were arranged in a randomized block design with four replicates per treatment. Treatments included a control and AG3 phosphonate drench concentrations applied once $(0.035,0.07$, and $0.14 \%$ a.i.) or twice $(0.035$ and $0.07 \%$ a.i.) after transplanting cabbage seedlings. Four rows of cabbage were planted $30 \mathrm{~cm}$ apart by hand. AG3 phosphonate drench solutions were prepared fresh at the site by mixing with tap water and applied as 30liter volumes per plot immediately after planting with watering cans. A second drench application was made 3 weeks after planting. Twelve plants with medium to large heads from the two middle rows from each plot were harvested and rated for clubroot severity using a 1-to-5 scale as described above. Cabbage heads from each plot were weighed together to determine fresh weight per plot.

Data analyses. Disease severity data were analyzed according to the KruskalWallis nonparametric test statistics. Analysis of variance was performed and means were separated according to the StudentNewman-Keuls test. Data on disease incidence and total fresh mass were subjected to analysis of variance using MINITAB statistical software (version 13; Minitab Inc., State College, PA) and means were separated according to Fisher's protected least significant difference test.

\section{RESULTS}

Effect on clubroot of bok choy. $M i$ croplots 2004. Bok choy produced in the muck soil collected from the two field locations showed different clubroot severity (Table 1). In trials 1 and 2 conducted in May and August with infested soil from Kettleby, the average clubroot severity on plants from untreated control soil was 2.0. In trials 3 and 4 conducted in June and July with infested muck soil from Holland Marsh, the average clubroot severity in the control ranged from 2.7 to 3.0 (Table 1).

In trial 1 , preplanting amendments of 0.07 and $0.14 \%$ a.i. and the postplanting drench of $0.14 \%$ a.i. AG3 phosphonate significantly reduced the severity of clubroot by 0.9 over the control (Table 1). In trial 2, only the $0.14 \%$ a.i. rate of AG3 phosphontae applied as a preplanting amendment or postplanting drench significantly reduced the clubroot severity by 0.8 over the control (Table 1). In trial 3, all three preplanting amendment $(0.035,0.07$, and $0.14 \%$ a.i.) and postplanting drench (0.07 and $0.14 \%$ a.i.) concentrations significantly reduced the severity of clubroot in the range of 0.9 to 2.0 compared with the control (Table 1 ). In trial 4 , only the $0.14 \%$ a.i. rate of AG3 phosphonate applied as a preplanting amendment and all postplanting drench concentrations significantly reduced the clubroot severity in the range of 0.8 to 1.5 compared with the control (Table 1).

In trial 1 , fresh weight of bok choy was not affected by any phosphonate treatment compared with the untreated control (Table 1). In trial 2 , the 0.07 and $0.14 \%$ a.i. rates of AG3 phosphonate applied as preplanting amendment or postplanting drench treatments significantly increased the fresh weight of bok choy by 47 to $76 \%$ compared with the untreated control (Table 1). In trial 3, all AG3 phosphonate treatments increased the fresh weight of bok choy by 74 to $155 \%$ over the control, with postplanting drenches performing better than preplanting amendment treatments (Table 1). In trial 4 , all preplanting amendment treatments and only lower postplanting drench concentration $(0.035 \%$ a.i. $)$ significantly increased the fresh weight of bok choy by 34 to $64 \%$ over the untreated control (Table 1).

Microplots 2005. In the June trials, AG phosphonate incorporated to soil prior to planting was effective at 0.07 and $0.14 \%$ a.i. rates in reducing the clubroot severity by 0.8 to 1.6 over the control, but not at $0.035 \%$ a.i. rate (Table 2). AG3 phosphonate drench applied once at 0.07 and $0.14 \%$ a.i. or twice at 0.035 and $0.07 \%$ a.i. after planting bok choy seed significantly reduced the severity of clubroot by 0.9 to 1.3 over the control (Table 2). In the July trials, phosphonate treatments incorporated into soil prior to planting bok choy seed or drenched after planting did not reduce clubroot severity, except for the postplanting drench rate of $0.14 \%$ a.i., which limited severity to 1.6 (Table 2). In the August trials, no phosphonate preplant applications resulted in reduced severity of clubroot (Table 2). Postplant applications applied once at 0.07 and $0.14 \%$ a.i. or twice

Table 1. Effect of phosphonate (AG3) preplanting amendment and postplanting drench applications on clubroot severity and fresh weight of bok choy in naturally infested muck soils in microplots during $2004^{\mathrm{x}}$

\begin{tabular}{|c|c|c|c|c|c|c|c|c|c|}
\hline \multirow[b]{3}{*}{$\operatorname{AG3}(\%$ a.i. $)$} & \multirow[b]{3}{*}{$\mathbf{A p p l}^{\mathrm{z}}$} & \multicolumn{8}{|c|}{ Trials $^{y}$} \\
\hline & & \multicolumn{4}{|c|}{ Clubroot severity } & \multicolumn{4}{|c|}{ Total fresh weight/microplot (g) } \\
\hline & & 1 & 2 & 3 & 4 & 1 & 2 & 3 & 4 \\
\hline 0.0 & & $2.0 \mathrm{a}$ & $2.0 \mathrm{a}$ & $3.1 \mathrm{a}$ & $2.7 \mathrm{a}$ & $660 \mathrm{a}$ & $237 \mathrm{~d}$ & $274 \mathrm{~d}$ & $354 \mathrm{~d}$ \\
\hline 0.035 & Pre & $1.3 \mathrm{ab}$ & $1.5 \mathrm{ab}$ & $2.2 \mathrm{~b}$ & $2.4 \mathrm{ab}$ & $703 \mathrm{a}$ & $254 \mathrm{~cd}$ & $478 \mathrm{c}$ & $473 \mathrm{bc}$ \\
\hline 0.07 & Pre & $1.1 \mathrm{~b}$ & $1.4 \mathrm{ab}$ & $2.0 \mathrm{~b}$ & $2.1 \mathrm{abc}$ & $723 \mathrm{a}$ & $349 a b c$ & $551 \mathrm{bc}$ & $582 \mathrm{a}$ \\
\hline 0.14 & Pre & $1.1 \mathrm{~b}$ & $1.2 \mathrm{~b}$ & $1.6 \mathrm{bc}$ & $1.8 \mathrm{bcd}$ & $656 \mathrm{a}$ & $358 \mathrm{ab}$ & $558 \mathrm{bc}$ & $509 a b c$ \\
\hline 0.035 & Post & $\ldots$ & $1.7 \mathrm{ab}$ & & $1.9 \mathrm{bcd}$ & $\ldots$ & $307 \mathrm{bcd}$ & & $523 \mathrm{ab}$ \\
\hline 0.07 & Post & . & $1.3 \mathrm{ab}$ & $1.4 \mathrm{bc}$ & $1.6 \mathrm{~cd}$ & & $367 \mathrm{ab}$ & $639 \mathrm{ab}$ & $417 \mathrm{~cd}$ \\
\hline 0.14 & Post & $1.1 \mathrm{~b}$ & $1.2 \mathrm{~b}$ & $1.1 \mathrm{c}$ & $1.2 \mathrm{~d}$ & 717 a & $417 \mathrm{a}$ & $698 \mathrm{a}$ & $360 \mathrm{~d}$ \\
\hline
\end{tabular}

${ }^{x}$ Values are the means of five replicates for each trial and, if followed by the same letter within each column, do not differ significantly according to the Student-Newman-Keuls test for clubroot severity and Fisher's protected least significant difference test for total fresh weight at $P \leq 0.05$. All plants from each microplot were harvested 5 weeks after planting and rated for clubroot severity using a 1-to-4 rating scale in which $1=0 \%$ (no club) and $4=>50 \%$ (large club) of root surface covered with club. After rating, plants were weighed to determine fresh weight.

y Trials 1 and 2 were conducted in May and August with infested muck soil from Muck Research Station, Kettleby, whereas trials 3 and 4 were conducted in June and July with infested muck soil from Holland Marsh.

${ }^{\text {z }}$ AG3 application. AG3 solutions were applied once as a preplanting (Pre) amendment or postplanting (Post) drench. 
at $0.07 \%$ a.i. significantly reduced clubroot severity by 0.8 to 1.5 compared with the control (Table 2). In the September trials, preplant application of $0.14 \%$ a.i. and postplanting drench concentrations applied once at rates of $0.035,0.07$, and $0.14 \%$ a.i. or twice at rates of 0.035 and $0.07 \%$ a.i. significantly reduced clubroot severity of bok choy in the range of 1.1 to 1.7 over the control (Table 2).

In the June trials, fresh weight of bok choy was significantly increased by 53 to $83 \%$ over the control by all AG3 phosphonate rates applied as preplanting amendment or postplanting drench treatments (Table 2). In the July trials, the overall total fresh weight was lower than June trials and only the $0.14 \%$ a.i. AG3 phosphonate rate applied as a postplanting drench significantly increased the plant fresh mass by $87 \%$ compared with the control (Table 2). In the August trials, only the drench rates of 0.07 and $0.14 \%$ a.i. applied once after planting increased the total fresh weight of bok choy by 72 to $80 \%$ compared with the control (Table 2). In the September trials, total fresh weight of bok choy was significantly increased by AG3 phosphonate applied as a preplanting amendment to soil (44 to 54\%) at 0.07 and $0.14 \%$ a.i. or as a postplanting drench $(62 \%)$ applied once at $0.035 \%$ a.i. compared with the control (Table 2).

Field trials. In the 2004 trial, all roots of plants harvested from the control plots were clubbed with an incidence of $100 \%$ and average disease severity rating of 3.7 (Table 3). All phosphonate postplanting drench treatments significantly reduced clubroot incidence by 52 to $87 \%$ over the control (Table 3 ). Severity of clubroot was reduced in the range of 1.7 to 2.5 over the control by drench applications of AG3 phosphonate. Phosphonate concentrations applied once ( 0.14 and $0.21 \%$ a.i.) or twice $(0.07 \%$ a.i. $)$ were equally effective in pro- viding disease control. Two drench applications with $0.07 \%$ a.i. phosphonate rate were better than a single application of $0.07 \%$ a.i. in reducing clubroot. Fresh weight of bok choy was increased (34 to $56 \%$ ) by phosphonate drench rates of $0.07 \%$ a.i. applied once or twice or $0.14 \%$ a.i. compared with the control (Table 3).

In 2005, the grower allowed us to carry out one field trial in June which was harvested in August. The weather was very dry in June and the grower had to irrigate the fields every day. None of the AG3 phosphonate treatment reduced the clubroot severity on bok choy (Table 3 ). However, fresh weight of bok choy was increased by 64 to $86 \%$ by phosphonate treatments compared with the untreated control (Table 3).

Effect on clubroot of cabbage. In the greenhouse trial, a single postplanting drench application of 0.07 and $0.14 \%$ a.i. AG3 phosphonate significantly reduced the severity of clubroot to 2.6 and 3.3 over the control, respectively (Table 4). The higher rate was more effective than the lower rate in reducing clubroot severity. The fresh weight of cabbage tops from AG3 phosphonate treatments was 66 to $69 \%$ more than the control (Table 4).

In the 2004 microplot trial, a single postplanting drench application of AG3 phosphonate at the $0.035 \%$ a.i. rate reduced the severity of clubroot to 0.9 compared with the control (Table 4). We also noticed that more than $90 \%$ of the control plants had club on main roots compared with $27 \%$ plants in the phosphonate treatment. Fresh weight of the cabbage heads was not affected by the phosphonate treatment (Table 4).

In the 2005 microplot trial, the incidence and severity of clubroot on cabbage grown in the muck soil from Holland Marsh was very high, with an average severity rating of 5.0 in the control. Most of the plants in the control plots were stunted due to severe clubroot infection, and very small cabbage heads developed on such plants compared with the plants in

Table 3. Effect of phosphonate (AG3) postplanting drench applications on the incidence and severity of clubroot and fresh weight of bok choy in naturally infested muck soils in Ontario commercial fields during 2004 and $2005^{y}$

\begin{tabular}{|c|c|c|c|c|c|c|}
\hline \multirow[b]{2}{*}{$\begin{array}{l}\text { AG3 } \\
(\% \text { a.i. })\end{array}$} & \multirow[b]{2}{*}{$\begin{array}{c}\text { No. of } \\
\text { drenches }^{\mathrm{z}}\end{array}$} & \multicolumn{3}{|c|}{2004 trial } & \multicolumn{2}{|c|}{2005 trial } \\
\hline & & $\begin{array}{c}\text { Clubroot } \\
\text { incidence }(\%)\end{array}$ & $\begin{array}{l}\text { Clubroot } \\
\text { severity }\end{array}$ & $\begin{array}{r}\text { Total fresh } \\
\text { weight }(\mathbf{k g})\end{array}$ & $\begin{array}{l}\text { Clubroot } \\
\text { severity }\end{array}$ & $\begin{array}{r}\text { Total fresh } \\
\text { weight (kg) }\end{array}$ \\
\hline 0.0 & $\ldots$ & $100 \mathrm{a}$ & $3.7 \mathrm{a}$ & $3.2 \mathrm{c}$ & $3.9 \mathrm{a}$ & $1.4 \mathrm{~b}$ \\
\hline 0.07 & 1 & $48 \mathrm{~b}$ & $2.0 \mathrm{~b}$ & $4.8 \mathrm{a}$ & $3.9 \mathrm{a}$ & $2.3 \mathrm{a}$ \\
\hline 0.14 & 1 & $24 \mathrm{c}$ & $1.5 \mathrm{bc}$ & $4.3 \mathrm{ab}$ & $3.8 \mathrm{a}$ & $2.6 \mathrm{a}$ \\
\hline 0.21 & 1 & $13 \mathrm{c}$ & $1.2 \mathrm{c}$ & $3.9 \mathrm{bc}$ & $\ldots$ & $\ldots$ \\
\hline 0.07 & 2 & $18 \mathrm{c}$ & $1.4 \mathrm{bc}$ & $5.0 \mathrm{a}$ & $3.8 \mathrm{a}$ & $2.3 \mathrm{a}$ \\
\hline
\end{tabular}

y Values are the means of four replicates ( 40 plants per replicate) and, if followed by the same letter within each column, do not differ significantly according to the Student-Newman-Keuls test for clubroot severity and Fisher's protected least significant difference test for clubroot incidence and total fresh weight at $P \leq 0.05$. From each replicate plot, 40 plants were harvested 8 weeks after planting and rated for clubroot severity using a 1-to-4 rating scale in which $1=0 \%$ (no club) and $4=$ $>50 \%$ (large club) of root surface covered with club. After rating plants were weighed to determine fresh weight.

${ }^{\mathrm{z}}$ AG3 drench solutions were applied immediately after planting. The second application was made 2 weeks after planting.

Table 2. Effect of phosphonate (AG3) preplanting amendment and postplanting drench applications on clubroot severity and fresh weight of bok choy in naturally infested muck soils in microplots during $2005^{\mathrm{x}}$

\begin{tabular}{|c|c|c|c|c|c|c|c|c|c|}
\hline \multirow[b]{3}{*}{$\operatorname{AG3}(\%$ a.i. $)$} & \multirow[b]{3}{*}{$\mathbf{A p p l}^{\mathbf{Z}}$} & \multicolumn{8}{|c|}{ Trials $^{y}$} \\
\hline & & \multicolumn{4}{|c|}{ Clubroot severity } & \multicolumn{4}{|c|}{ Total fresh weight/microplot (g) } \\
\hline & & June & July & August & September & June & July & August & September \\
\hline 0.0 & $\ldots$ & $2.9 \mathrm{a}$ & $3.3 \mathrm{a}$ & $3.3 \mathrm{a}$ & $2.8 \mathrm{a}$ & $326 \mathrm{~b}$ & $175 \mathrm{bc}$ & $207 \mathrm{bc}$ & $274 \mathrm{~cd}$ \\
\hline 0.035 & $1 \times$ Pre & $2.8 \mathrm{ab}$ & $3.4 \mathrm{a}$ & $3.6 \mathrm{a}$ & $2.4 \mathrm{ab}$ & $500 \mathrm{a}$ & $164 \mathrm{c}$ & $180 \mathrm{c}$ & $328 \mathrm{bc}$ \\
\hline 0.07 & $1 \times$ Pre & $2.1 \mathrm{bcd}$ & $3.2 \mathrm{a}$ & $3.4 \mathrm{a}$ & $2.5 \mathrm{ab}$ & $541 \mathrm{a}$ & $185 \mathrm{bc}$ & $173 \mathrm{c}$ & $422 \mathrm{ab}$ \\
\hline 0.14 & $1 \times$ Pre & $1.3 \mathrm{e}$ & $3.2 \mathrm{a}$ & $3.2 \mathrm{ab}$ & $1.4 \mathrm{~b}$ & $597 \mathrm{a}$ & $238 \mathrm{abc}$ & $246 \mathrm{bc}$ & $394 \mathrm{ab}$ \\
\hline 0.035 & $1 \times$ Post & $2.3 \mathrm{a}-\mathrm{d}$ & $3.1 \mathrm{a}$ & $3.1 \mathrm{ab}$ & $1.7 \mathrm{bc}$ & $519 \mathrm{a}$ & $165 \mathrm{c}$ & $242 \mathrm{bc}$ & $443 \mathrm{a}$ \\
\hline 0.07 & $1 \times$ Post & $1.9 \mathrm{cde}$ & $2.8 \mathrm{a}$ & $2.5 \mathrm{bc}$ & $1.2 \mathrm{c}$ & $547 \mathrm{a}$ & $253 \mathrm{abc}$ & $356 \mathrm{a}$ & $352 a b c$ \\
\hline 0.14 & $1 \times$ Post & $1.6 \mathrm{de}$ & $1.6 \mathrm{~b}$ & $1.8 \mathrm{c}$ & $1.1 \mathrm{c}$ & $510 \mathrm{a}$ & $327 \mathrm{a}$ & $373 \mathrm{a}$ & $217 \mathrm{~d}$ \\
\hline 0.035 & $2 \times$ Post & $2.0 \mathrm{cde}$ & $2.9 \mathrm{a}$ & $3.0 \mathrm{ab}$ & $1.4 \mathrm{c}$ & $534 \mathrm{a}$ & $174 \mathrm{c}$ & $220 \mathrm{bc}$ & $365 a b c$ \\
\hline 0.07 & $2 \times$ Post & $1.8 \mathrm{de}$ & $2.7 \mathrm{a}$ & $2.5 \mathrm{bc}$ & $1.2 \mathrm{c}$ & $511 \mathrm{a}$ & $275 \mathrm{ab}$ & $293 \mathrm{ab}$ & $302 \mathrm{~cd}$ \\
\hline 0.035 & Pre + Post & $2.6 \mathrm{ab}$ & $3.1 \mathrm{a}$ & $3.3 \mathrm{a}$ & $3.1 \mathrm{a}$ & $565 \mathrm{a}$ & $160 \mathrm{c}$ & $189 \mathrm{c}$ & 342 bc \\
\hline
\end{tabular}

${ }^{x}$ Values are the means of two experiments (10 plants per replicate per experiment per trial) and, if followed by the same letter within each column, do not differ significantly according to the Student-Newman-Keuls test for clubroot severity and Fisher's protected least significant difference test for total fresh weight at $P \leq 0.05$. All plants from each microplot were harvested 5 weeks after planting and rated for clubroot severity using a 1 -to- 4 rating scale in which $1=0 \%$ (no club) and $4=>50 \%$ (large club) of root surface covered with club. After rating, plants were weighed to determine fresh weight.

y Soil from Holland Marsh was used for June, July, and August trials, whereas soil from Muck Research Station, Kettleby, was used in September trials.

${ }^{\mathrm{z}}$ AG3 application. All AG3 solutions were applied once $(1 \times)$ as a preplanting (Pre) amendment or once or twice $(2 \times)$ as a postplanting $($ Post) drench. The second application was applied 2 weeks after planting. 
the AG3 phosphonate-treated plots. One and two postplanting drench applications of AG3 phosphonate significantly reduced the severity of clubroot in the range of 1.2 to 2.8 over the control (Table 4). Cabbage heads from the AG3 phosphonate treatments were six to nine times heavier than the control (Table 4).

In the 2004 field trial, the overall incidence and severity of clubroot on cabbage plants was low in the Kettleby plots. Although a single postplanting drench application of $0.035 \%$ a.i. phosphonate reduced the clubroot severity on 'Saragota' cabbage (Table 4), fresh weight of cabbage heads was not affected by the phosphonate treatment (data not shown).

In the 2005 field trial, all AG3 phosphonate concentrations applied once or twice as a drench after transplanting cabbage seedlings significantly reduced the severity of clubroot by 0.7 to 1.5 compared with the control (Table 4). The average fresh weight of cabbage heads from field plots receiving phosphonate treatments was not different from the control plots because we picked only medium to large heads from all the plots (data not shown).

\section{DISCUSSION}

Clubroot has been partially responsible for shrinkage of cole crop acreages on organic or muck soils in Ontario, and now is a limiting factor in production of Asian brassica vegetable crops (26). Growers have limited options available to manage this problem and minimize losses. They heavily rely on lime applications for clubroot management $(30,32)$; however, the results are not always consistent because it is difficult to increase the $\mathrm{pH}$ of these highly buffered soils. Calcium cyanamid, a slow-release granulated fertilizer, has shown great potential against clubroot $(4,10,21,26)$, but it must be applied 1 to 2 weeks before seeding. Several clubroot management options are mentioned in the introduction; however, thus far, growers have no access to any single product that could give consistent disease control and fit well in their routine cultivation practices. In this study, we report a low-risk chemical option to control clubroot. As far as we know, this is the first report describing the efficacy of phosphonates against clubroot.

Both preplanting amendment and postplanting drench applications of AG3 phosphonate reduced the severity of clubroot on bok choy and cabbage. The postplanting drench treatments generally performed better than the preplanting treatments. The higher rates of AG3 phosphonate ( 0.07 and $0.14 \%$ a.i.) provided the most consistent control of clubroot of bok choy and cabbage. The control of clubroot of bok choy was consistent in microplot trials planted in May, June, or September. The reduced efficacy in phosphonate treatments during the months of July and August may have been due to dilution of the product by extra irrigation or rainfall. Plant fresh weight was increased or not affected by AG3 phosphonate treatments in the microplot or field trials. The variability in yields we encountered may result from the fact that, when sufficient water is provided, even plants with clubbed roots can provide good yields. However, if insufficient water is available, these plants collapse and die.

Phosphonates are directly toxic to target pathogens but also may protect plants by enhancing the defense potential of the treated plant against the invading pathogen $(14,15)$. Phosphonates generally are considered to have low phytotoxicity (16); however, the negative effects on plant growth and development have been documented under phosphate-limiting conditions (5) which could be overcome by phosphate supplementation. Also, excessive concentrations can result in severe phytotoxicity $(17,36)$. In our microplot and field trials, at the concentrations used, AG3 phosphonate never showed any phytotoxicity to bok choy or cabbage in either year of tests. In fact, plant fresh mass was increased in most of the cases, but that was because of disease control. Because AG3 phosphonate also is effective against $P y$ thium spp. $(1,2)$, it is possible that an increase in fresh plant weight of bok choy may have been affected. Although rates higher than $0.21 \%$ a.i. may provide excellent clubroot control, they may not be economical and may be phytotoxic.

Bok choy often is harvested within 30 to 35 days after planting and growers try to have four or five consecutive crops from the same field in one season; therefore, it is important to monitor the efficacy of a product during the entire growing season. Results of tests planted during May to September indicate some variability in efficacy. We attribute this to dilution of the product due to rainfall or heavy irrigation. Clubroot also can increase over time due to build up of inoculum in the field due to plowing into soil of clubbed roots from preceding crops (28). However, that was not the case in microplots, where soil was removed after harvesting each trial and replaced with the fresh soil for a new trial. It is necessary to further explore this variability in efficacy during the months of July and August.

In conclusion, this is the first report demonstrating the efficacy of phosphonates to control clubroot on bok choy and cabbage in naturally infested muck soils under both microplot and field conditions. It may be useful to test different formulations of phosphonate products that contain higher active ingredient contents than the AG3 phosphonate. Based on our experience, we suggest that further studies be undertaken to optimize the methods and timing of application of phosphonate to achieve the most cost-effective control of clubroot.

Table 4. Effect of phosphonate (AG3) postplanting drench applications on clubroot severity and fresh weight of cabbage in naturally infested muck soils in greenhouse, microplot, and field trials $\mathrm{v}$

\begin{tabular}{|c|c|c|c|c|c|c|c|c|c|}
\hline \multirow{4}{*}{$\begin{array}{l}\text { AG3 } \\
(\% \text { a.i. })\end{array}$} & \multirow{4}{*}{$\begin{array}{c}\text { No. of } \\
\text { drenches }^{\mathrm{z}}\end{array}$} & & & \multicolumn{4}{|c|}{ Microplot trials $^{w}$} & & \\
\hline & & \multicolumn{2}{|c|}{ Greenhouse trial $^{\mathrm{x}}$} & \multicolumn{2}{|c|}{2004} & \multicolumn{2}{|c|}{2005} & \multirow{2}{*}{\multicolumn{2}{|c|}{$\begin{array}{c}\text { Field trials }^{\mathrm{y}} \\
\text { Clubroot severity }\end{array}$}} \\
\hline & & \multirow{2}{*}{$\begin{array}{l}\text { Clubroot } \\
\text { severity }\end{array}$} & \multirow{2}{*}{$\begin{array}{l}\text { Fresh weight/ } \\
\text { plant (g) }\end{array}$} & \multirow{2}{*}{$\begin{array}{l}\text { Clubroot } \\
\text { severity }\end{array}$} & \multirow{2}{*}{$\begin{array}{l}\text { Fresh weight/ } \\
\text { plant (kg) }\end{array}$} & \multirow{2}{*}{$\begin{array}{l}\text { Clubroot } \\
\text { severity }\end{array}$} & \multirow{2}{*}{$\begin{array}{l}\text { Fresh weight/ } \\
\text { plot (kg) }\end{array}$} & & \\
\hline & & & & & & & & 2004 & 2005 \\
\hline 0.0 & $\ldots$ & $4.8 \mathrm{a}$ & $32 \mathrm{~b}$ & $3.5 \mathrm{a}$ & $1.69 \mathrm{a}$ & $5.0 \mathrm{a}$ & $0.1 \mathrm{~b}$ & $2.7 \mathrm{a}$ & $3.0 \mathrm{a}$ \\
\hline 0.035 & 1 & $2.2 \mathrm{~b}$ & $53 \mathrm{a}$ & $2.6 \mathrm{~b}$ & $1.64 \mathrm{a}$ & $4.3 \mathrm{ab}$ & $0.7 \mathrm{a}$ & $2.0 \mathrm{~b}$ & $2.2 \mathrm{bc}$ \\
\hline 0.07 & 1 & $1.5 \mathrm{c}$ & $54 \mathrm{a}$ & $\ldots$ & $\ldots$ & $3.2 \mathrm{c}$ & $0.8 \mathrm{a}$ & $\ldots$ & $2.3 \mathrm{~b}$ \\
\hline 0.14 & 1 & $\ldots$ & $\ldots$ & $\ldots$ & $\ldots$ & $2.2 \mathrm{~d}$ & $1.0 \mathrm{a}$ & $\ldots$ & $1.6 \mathrm{~cd}$ \\
\hline 0.035 & 2 & $\ldots$ & $\ldots$ & $\ldots$ & $\ldots$ & $3.8 \mathrm{bc}$ & $0.7 \mathrm{a}$ & $\ldots$ & $2.0 \mathrm{bcd}$ \\
\hline 0.07 & 2 & $\ldots$ & $\ldots$ & $\ldots$ & $\ldots$ & $3.3 \mathrm{c}$ & $0.9 \mathrm{a}$ & $\ldots$ & $1.5 \mathrm{~d}$ \\
\hline
\end{tabular}

${ }^{v}$ Values are the means of 11 replicates in 2004 and 4 replicates in 2005 (one plant per replicate in 2004 and five plants per replicate in 2005) and, if followed by the same letter within each column, do not differ significantly according to the Student-Newman-Keuls test for disease severity and Fisher's protected least significant difference test for fresh weight at $P \leq 0.05$. Plants were rated for clubroot severity using a 1 -to-5 rating scale in which $1=$ none and $5=$ $>76 \%$ of root surface covered with club.

${ }^{\text {w }}$ All plants from each microplot were harvested 8 weeks after planting in 2004 trial and 10 weeks after planting in 2005 trial, and rated for clubroot severity.

${ }^{x}$ Plants were rated for clubroot severity and fresh weight of cabbage tops was determined 6 weeks after planting.

y The 2004 trial was conducted at Kettleby Muck Research Station with 'Saratoga' cabbage and the 2005 trial was conducted at Holland Marsh with Chinese cabbage. Twelve plants were harvested 8 weeks after planting from two middle rows of each replicate plots and rated for clubroot severity.

${ }^{\mathrm{z}}$ AG3 drench solutions were applied after planting. The second application was applied 3 weeks after planting. 


\section{ACKNOWLEDGMENTS}

This research was funded by grants from Agricare Ltd. and the Agriculture and Agri-Food Canada Matching Investment Initiative. We thank A. Molnar, B. Weselowski, E. Seip, D. Masters, J. Monast, J. Park, and R. Earl for providing technical assistance; Best Asia Farms, Ltd. (Holland Marsh, Ontario) and M. R. McDonald and her team at University of Guelph Muck Research Station (Kettleby, Ontario) for providing assistance in field work and collecting soil samples; and J. Traquair and K. Conn Agriculture and Agri-Food Canada, London, Ontario for critically reviewing the manuscript.

\section{LITERATURE CITED}

1. Abbasi, P. A., and Lazarovits, G. 2005. Effects of AG3 phosphonate formulations on incidence and severity of Pythium damping-off of cucumber seedlings under growth room, microplot, and field conditions. Can. J. Plant Pathol. 27:420-429.

2. Abbasi, P. A., and Lazarovits, G. 2006. Seed treatment with phosphonate (AG3) suppresses Pythium damping-off of cucumber seedlings. Plant Dis. 90:459-464.

3. Arie, T., Kobayashi, Y., Okada, G., Kono, Y., and Yamaguchi, I. 1998. Control of soilborne clubroot disease of cruciferous plants by epoxydon from Phoma glomerata. Plant Pathol. 47:743-748.

4. Bélec, C., Tremblay N., and Coulombe, J. 2004. Liming and calcium cyanamid for clubroot control in cauliflower. Acta Hortic. 635:41-46.

5. Carswell, C., Grant, B. R., Theodorou, M. E., Harris, J., Niere, J. O., and Plaxton, W. C. 1996. The fungicide phosphonate disrupts the phosphate-starvation response in Brassica nigra seedlings. Plant Physiol. 110:105-110.

6. Cohen, Y., and Coffey, M. D. 1986. Systemic fungicides and the control of oomycetes. Annu. Rev. Phytopathol. 24:311-338.

7. Cook, L. R., and Little, G. 2001. The effect of foliar application of phosphonate formulations on the susceptibility of potato tubers to late blight. Pest Manage. Sci. 58:17-25.

8. Darvas, J. M., Toerien, J. C., and Milne, D. L. 1984. Control of avocado root rot by trunk injection with phosethyl-Al. Plant Dis. 68:691693.

9. Davis, A. G., Say, M., Snow, A. J., and Grant, B. R. 1994. Sensitivity of Fusarium oxysporum f. sp. cubense to phosphonate. Plant Pathol. 43:200-205.

10. Donald, E. C., Lawrence, J. M., and Porter, I. J. 2004. Influence of particle size and application method on the efficacy of calcium cyanamide for control of clubroot of vegetable brassicas. Crop Prot. 23:297-303.

11. Donald, E. C., Porter, I. J. and Lancaster, R. A. 2001. Band incorporation of fluazinam (shirlan) into soil to control clubroot of vegetable Brassica crops. Aust. J. Exp. Agric. 41:12231226.

12. El-Hamalawi, Z. A., Menge, J. A., and Adams, C. J. 1995. Methods of fosetyl-Al application and phosphonate levels in avocado tissue needed to control stem canker caused by Phytophthora citricola. Plant Dis. 79:770-778.

13. Fähling, M., Graf, H., and Siemens, J. 2003. Pathotype separation of Plasmodiophora bras- sicae by the host plant J. Phytopathol. 151:425-430

14. Grant, B. R., Dunstan, R. H., Griffith, J. M., Niere, J. D., and Smillie, R. H. 1990. The mechanism of phosphonic (phosphorous) acid action in Phytophthora. Australas. Plant Pathol. 19:115-121.

15. Guest, D. I., and Bompeix, G. 1990. The complex mode of action of phosphonates. Australas. Plant Pathol. 19:113-115.

16. Guest, D. I., and Grant, B. 1991. The complex action of phosphonates as antifungal agents. Biol. Rev. 66:159-187.

17. Hardy, G. E. St. J., Barrett, S., and Shearer, B. L. 2001. The future of phosphite as a fungicide to control the soilborne plant pathogen Phytophthora cinnamomi in natural ecosystems. Australas. Plant Pathol. 30:133-139.

18. Hata, S., Sumi, Y., and Ohi, M. 2002. Dry powder and extract of Posidonia australis Hook. F., a species of seagrass, stimulate the germination of the pathogen Plasmodiophora brassicae and control clubroot of Chinese cabbage. J. Jpn. Soc. Hortic. Sci. 71:197-202.

19. Hildebrand, P. D., and McRae, K. D. 1998. Control of clubroot caused by Plasmodiophora brassicae with nonionic surfactants. Can. J. Plant Pathol. 20:1-11.

20. Hirai, M., Harada, T., Kubo, N., Tsukada, M., Suwabe, K., and Matsumoto, S. 2004. A novel locus for clubroot resistance in Brassica rapa and its linkage markers. Theor. Appl. Genet. 108:639-643.

21. Klasse, H. J. 1996. Calcium cyanamide-an effective tool to control clubroot-a review. Acta Hortic. 407:403-409.

22. Kuginuki, Y., Yoshikawa, H., and Hirai, M. 1999. Variation in virulence of Plasmodiophora brassicae in Japan tested with clubrootresistant cultivars of Chinese cabbage (Brassica rapa L. ssp. pekinensis). Eur. J. Plant Pathol. 105:327-332.

23. Ludwig-Müller, J. 1999. Plasmodiophora brassicae, the causal agent of clubroot disease: a review on molecular and biochemical events in pathogenesis. Z. Pflanzenkrankh. Pflanzenschutz 106:109-127.

24. Manzanares-Dauleux, M. J., Divaret, I., Baron, F., and Thomas, G. 2001. Assessment of biological and molecular variability between and within field isolates of Plasmodiophora brassicae. Plant Pathol. 50:165-173.

25. Marks, G. C., and Smith, W. 1992. Metalaxyl and phosphonate as prophylactic and curative agents against stem infection of Leucadendron caused by Phytophthora cinnamomi. Aust. J. Exp. Agric. 32:255-259.

26. McDonald, M. R., Kornatowska, B., and McKeown, A. W. 2004. Management of clubroot of Asian brassica crops grown on organic soils. Acta Hortic. 635:25-30.

27. Mitani, S., Sugimoto, K., Hayashi, H., Takii, Y., Ohshima, T., and Matsuo, N. 2003. Effects of cyazofamid against Plasmodiophora brassicae Woronin on Chinese cabbage. Pest Manage. Sci. 59:287-293.

28. Murakami, H., Tsushima, S., Akimoto, T., Kuroyanagi, Y., and Shishido, Y. 2004. Quantitative studies on the relationship between plowing into soil of clubbed roots of preceding crops caused by Plasmodiophora brassicae and disease severity in succeeding crops. Soil
Sci. Plant Nutr. 50:1307-1311.

29. Murakami, H., Tsushima, S., Akimoto, T. Murakami, K., Goto, I., and Shishido, Y. 2000. Effects of growing leafy daikon (Raphanus sativus) on populations of Plasmodiophora brassicae (clubroot). Plant Pathol. 49:584-589.

30. Murakami, H., Tsushima, S., Kuroyanagi, Y., and Shishido, Y. 2002. Reduction of resting spore density of Plasmodiophora brassicae and clubroot disease severity by liming. Soil Sci. Plant Nutr. 48:685-691.

31. Murakami, H., Tsushima, S., and Shishido, Y. 2000. Soil suppressiveness to clubroot disease of Chinese cabbage caused by Plasmodiophora brassicae. Soil Biol. Biochem. 32:16371642

32. Myers, D. F., and Campbell, R. N. 1985. Lime and the control of clubroot of crucifers: Effects of $\mathrm{pH}$, calcium, magnesium, and their interactions. Phytopathology 75:670-673.

33. Narisawa, K., Tokumasu, S., and Hashiba, T. 1998. Suppression of clubroot formation in Chinese cabbage by the root endophytic fungus, Heteroconium chaetospira. Plant Pathol. 47:206-210.

34. Ohi, M., Kitamura, T., and Hata, S. 2003. Stimulation by caffeic acid, coumalic acid, and corilagin of the germination of resting spores of the clubroot pathogen Plasmodiophora brassicae. Biosci. Biotechnol. Biochem. 67:170-173.

35. Panicker, S., and Gangadharan, K. 1999. Controlling downy mildew of maize caused by Peronosclerospora sorghi by foliar sprays of phosphonic acid compounds. Crop Prot. 18:115-118.

36. Pilbeam, R. A., Colquhoun, I. J., Shearer, B. and Hardy, G. E. St. J. 2000. Phosphite concentration: its effect on phytotoxicity symptoms and colonisation by Phytophthora cinnamomi in three understorey species of Eucalyptus marginata forest. Australas. Plant Pathol. 29:86-95.

37. Porter, I. J., Donald, E. C., and Cross, S. J. 1998. Field evaluation of fluazinam against clubroot (Plasmodiophora brassicae) of cruciferous vegetable crops. Ann. Appl. Biol. 132:12-13.

38. Rocherieux, J., Glory, P., Giboulot, A., Boury, S., Barbeyron, G., Thomas, G., and Manzanares-Dauleux, M. J. 2004. Isolate-specific and broad-spectrum QTLs are involved in the control of clubroot in Brassica oleracea. Theor. Appl. Genet. 108:1555-1563.

39. Tanaka, S., Kochi, S., Kunita, H., Ito, S., and Kameya-Iwaki, M. 1999. Biological mode of action of the fungicide, flusulfamide, against Plasmodiophora brassicae (clubroot). Eur. J. Plant Pathol. 105:577-584.

40. Wicks, T. J., Magarey, P. A., Wachtel, H. F., and Frensham, A. B. 1991. Effect of post infection application of phosphonic acid on Plasmopara citricola on grapevine. Plant Dis. 75:40-43.

41. Worku, Y., and Gerhardson, B. 1996. Suppressiveness to clubroot, pea root rot and Fusarium wilt in Swedish soils. J. Phytopathol. 144:143146.

42. Young, C. C., Cheng, K. T., and Waller, G. R. 1991. Phenolic compounds in conducive and suppressive soils on clubroot disease of crucifers. Soil Biol. Biochem. 23:1183-1189. 